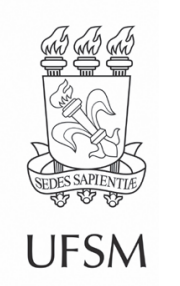

\title{
Artigos
}

\section{Influence of the depreciation method on the wood transport cost}

Influência do método de depreciação no custo de transporte de madeira

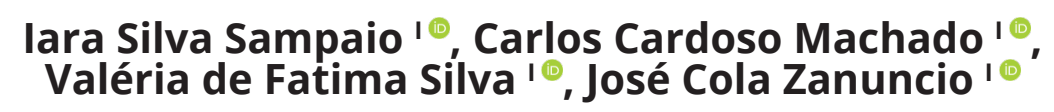

'Universidade Federal de Viçosa, Viçosa, MG, Brazil

\begin{abstract}
Wood transport, predominantly made by road in Brazil, represents one of the most costly segments of this sector. Depreciation, one of the fixed costs in forestry production, is included in the use and replacement of machines. Their depreciation is calculated by different methods and the best ones should be used to improve costs in wood industry. The objective of this study was to evaluate the influence of four depreciation methods on the cost of forest road transportation. The depreciation methods used were: Caires, Cole, Exponential and Linear. The depreciation and transportation costs were determined using the freight cost simulation spreadsheet for the Road Transportation of Loads, developed by the Agência Nacional de Transportes Terrestres (ANTT). The monthly depreciation of the truck was $R \$ 1,630.25, R \$ 2,276.64, R \$ 2,400.96$ and $R \$ 2,422.40$ with the Caires, Exponential, Linear and Cole methods, respectively. The lowest transport cost was $R \$ 13.71$ with the Caires method, followed by $\mathrm{R} \$ 13.72, \mathrm{R} \$ 16.72$ and $\mathrm{R} \$ 16.92$ from the Linear, Cole and Exponential methods, respectively. The lower values of depreciation and transport cost per ton obtained by the Caires method are due to this method considering factors other than the current age and the useful life of the machine and adjusting the model and the coefficients of use for specific situations. This portrays the situations found in the field, generating costs closer to the real ones. The best estimation of the depreciation and wood transport cost was obtained with the Caires method in all the studied situations, evidencing the need to consider maintenance and labor factors in its calculation. The adoption of this method also represents a great saving of financial resources in the long term.
\end{abstract}

Keywords: Fixed cost; Linear depreciation; Caires method; Forest transport 


\section{RESUMO}

O transporte de madeira no Brasil, predominantemente rodoviário, representa um dos segmentos mais onerosos do setor. A depreciação, um dos custos fixos na produção florestal, é incluída na utilização e substituição de máquinas. Essa depreciação pode ser calculada por meio de diferentes métodos, e os melhores devem ser utilizados para aperfeiçoar os custos nessa área. O objetivo deste estudo foi avaliar a depreciação de um caminhão e o custo de transporte rodoviário florestal, usando quatro métodos de análise: Caires, Cole, Exponencial e Linear. Os custos de depreciação e de transporte foram determinados utilizando a planilha de simulação de custos de frete para o Transporte Rodoviário de Cargas, desenvolvida pela Agência Nacional de Transportes Terrestres (ANTT). Constatou-se que a depreciação mensal do caminhão foi de $R \$ 1.630,25$, $R \$ 2.276,64$, $R \$ 2.400,96$ e $R \$ 2.422,40$, calculada pelos métodos de Caires, Exponencial, Linear e de Cole, respectivamente. O menor custo de transporte foi de $R \$ 13,71$, obtido pelo método de Caires, seguido de $R \$ 13,72$, $R \$ 16,72$ e $R \$ 16,92$, obtidos pelos métodos Linear, Cole e Exponencial, respectivamente. Os menores valores de depreciação e custo de transporte por tonelada obtidos pelo método de Caires se devem ao fato de esse método considerar outras variáveis, além da idade atual e da vida útil da máquina, e ajustar o modelo e os coeficientes de utilização para situações específicas. Isso retrata as condições encontradas em campo, portanto gera custos próximos aos reais. A estimativa da depreciação de transporte florestal foi melhor pelo método de Caires, em todas as situações estudadas, o que evidencia a necessidade de considerar fatores de manutenção e trabalho no cálculo da depreciação. A adoção desse método também representa grande economia de recursos financeiros no longo prazo.

Palavras-chave: Custo fixo; Depreciação linear; Método de Caires; Transporte florestal

\section{INTRODUCTION}

Wood transport in Brazil is predominantly made by road and is one of the stages with the highest logistic cost (Alves et al., 2013), evidencing the importance of evaluating costs and factors that affect it (GUIMARÃES et al., 2016).

Fixed costs are related to the use of machinery and the variables depend on its use intensity (PIACENTINI et al., 2012). Machine depreciation is an item that most influences the final costs (SILVA et al., 2014) representing a fixed cost in forest production (JASPER; SILVA, 2013). Depreciation costs arise from machine wear through use, nature action or normal obsolescence (FREITAS et al., 2007).

Depreciation rates are factors that strongly influence the variation in hourly costs for machinery assemblies (BAIO et al., 2004). The diversity of methods to calculate the depreciation of forest machinery and equipment requires selecting the best ones, due 
to the different depreciation forms of a machine or equipment (FREITAS et al., 2007). The most used depreciation models in the forestry sector include only the values of acquisition, resale and the useful life of the vehicle. Caires method has increased its use in the forest scenario by considering factors of use and maintenance of the machines (SILVA et al., 2009).

The Caires method approximates a curve that determines the depreciated value over the useful life of the machine as a function of the age of the good $(\mathrm{t})$, the maintenance practices $(\mu)$, the working regime $(\tau)$ and the expected useful life ( $\eta$ ) (SILVA et al., 2009). This method has great applicability in the evaluation of machines and equipment, being based on market data and, therefore, with a wide scope of application (BENVENHO; SABINO, 2013). The Linear method, used in several market sectors, uses fixed depreciation quotas per year of machine life (OLIVEIRA; MILAN, 2001). The Exponential method, also called the Matheson one, is based on a falling rate of depreciation on the residual value of the period observed in the previous year. The Cole, or series, method establishes the empirical depreciation per $\mathrm{n}$ time period (OLIVEIRA, 2003). The need to define a residual arbitrary value is difficult when using the three latter methods to design depreciation and transport costs.

The objective of this study was to evaluate the influence of four depreciation methods on the cost of forest road transportation.

\section{MATERIAL AND METHODS}

\subsection{Technical aspects}

The vehicle studied was a load composition vehicle (VLC) with a $6 \times 4$ traction and three tandem semi-trailers, called forest tritrem, with an acquisition value of $R \$ 300,000.00$.

The monthly depreciation and the transportation cost of wood were calculated with a freight cost simulator for the Transporte Rodoviário de Cargas - TRC (ANTT, 2015). This simulator uses the vehicle's acquisition, resale values, useful life, average monthly mileage, payload capacity and the average distance between loading and unloading as inputs. 
The average forest transport distance and payload capacity considered were 100 $\mathrm{km}$ and 54 tonnes, respectively.

Seven situations were based on the km traveled per month and years of the truck's useful life. The km traveled per month was based on the average monthly mileage in the wood transport of forestry companies. The variation between 5,000 and 20,000 km traveled monthly was determined (Table 1) to ensure the representativeness that these activities developed in the sector.

Table 1 - Average monthly mileage in km according to the machine useful life, in years, for each studied situation

\begin{tabular}{lccccccc}
\hline Situation & A & B & C & D & E & F & G \\
\hline UL & 2.08 & 2.38 & 2.78 & 3.33 & 4.17 & 5.56 & 8.33 \\
KM/M & 20000 & 17500 & 15000 & 12500 & 10000 & 7500 & 5000 \\
\hline
\end{tabular}

Source: Authors (2018)

In where: $\mathrm{UL}$ = useful machine life; $\mathrm{KM} / \mathrm{M}$ = average monthly mileage.

The useful truck life was defined based on the premise that a forest trithrem travels $500,000 \mathrm{~km}$, average of the Brazilian forest scenario, during the useful life of the truck.

\subsection{Calculation of depreciation coefficients and resale value}

The depreciation coefficients were calculated based on the truck's useful life and monthly mileage per situation. The resale value of the machine, to be inserted in the TRC simulator (1.0 version), was calculated with these coefficients.

The coefficients of depreciation by the Cole, Exponential and Linear methods were calculated with the Equations (1), (2), and (3).

$$
\begin{aligned}
& D p=2\left(V_{o}-V_{r}\right) / n(n+1) \\
& D A=1-\left(V_{r} / V_{a}\right)^{1 / n} \\
& D=\left(V_{a}-V_{r}\right) / n
\end{aligned}
$$

In where: $D, D A$ and $D p$ : depreciation ( $\$ \$ /$ year); $V a$ : acquisition value $(\mathrm{R} \$) ; V r$ : resale value $(\mathrm{R} \$$ ) and $n$ : useful life (years) (OLIVEIRA 2000; IBAPE 2007). 
The resale values were established using the Linear, Exponential and Cole methods considering a distribution range of arbitrary values of depreciation by use situation and truck life (Table 2). This represents the variability in use of different depreciation rates of forest machines.

Table 2 - Useful life in years, arbitrary depreciation value and truck resale value in $\mathrm{R} \$$, obtained with the Linear, Exponential and Cole methods, in $\mathrm{R} \$$, for each studied situation

\begin{tabular}{|c|c|c|c|c|c|}
\hline Situation & UL & ADV & $\mathrm{RV}_{\mathrm{L}}$ & $\mathrm{RV}_{\mathrm{E}}$ & $\mathbf{R V}_{\text {co }}$ \\
\hline \multirow{2}{*}{ A } & \multirow{2}{*}{2.08} & $70 \%$ & 210000 & 47205.10 & 58378.38 \\
\hline & & $80 \%$ & 240000 & 30471.65 & 38918.92 \\
\hline \multirow{2}{*}{ B } & \multirow{2}{*}{2.38} & $60 \%$ & 180000 & 57927.88 & 70985.92 \\
\hline & & $70 \%$ & 210000 & 41736.86 & 53239.44 \\
\hline \multirow{2}{*}{ C } & \multirow{2}{*}{2.78} & $50 \%$ & 150000 & 66250.63 & 79411.76 \\
\hline & & $60 \%$ & 180000 & 50393.61 & 63529.41 \\
\hline \multirow{2}{*}{ D } & \multirow{2}{*}{3.33} & $40 \%$ & 120000 & 72102.66 & 83076.92 \\
\hline & & $50 \%$ & 150000 & 56324.28 & 69230.77 \\
\hline \multirow{2}{*}{$E$} & \multirow{2}{*}{4.17} & $30 \%$ & 90000 & 75285.88 & 81290.32 \\
\hline & & $40 \%$ & 120000 & 59222.64 & 69677.42 \\
\hline \multirow{2}{*}{$F$} & \multirow{2}{*}{5.56} & $20 \%$ & 60000 & 75453.31 & 73220.34 \\
\hline & & $30 \%$ & 90000 & 58452.20 & 64067.80 \\
\hline \multirow{2}{*}{ G } & \multirow{2}{*}{8.33} & $10 \%$ & 30000 & 72426.73 & 57857.14 \\
\hline & & $20 \%$ & 60000 & 52688.19 & 51428.57 \\
\hline
\end{tabular}

Fonte: Authors (2018)

In where: $U L=$ useful machine life; $A D V=$ arbitrary depreciation value; $R V_{L}=$ truck resale value obtained with the Linear method; $\mathrm{RV}_{\mathrm{E}}=$ truck resale value obtained with the Exponential method; $\mathrm{RV}_{\mathrm{Co}_{\mathrm{o}}}=$ truck resale value obtained with the Cole method.

The depreciation coefficients and resale values, obtained by the Caires method, were calculated by extrapolation of those predefined by the Instituto Brasileiro de Avaliações e Perícias de Engenharia - IBAPE (Table 3).

The values of depreciation and transport cost per woodton were generated with the outputs of the TRC simulator. 
Table 3 - Useful life in years, depreciation coefficient and resale truck value in $\mathrm{R} \$$ obtained by the Caires method, in $\mathrm{R} \$$, for each studied situation

\begin{tabular}{lccccccc}
\hline Situation & A & B & C & D & E & F & G \\
\hline UL & 2.08 & 2.38 & 2.78 & 3.33 & 4.17 & 5.56 & 8.33 \\
DC & 0.795 & 0.777 & 0.753 & 0.720 & 0.670 & 0.592 & 0.457 \\
RV $_{\text {Ca }}$ & 238560 & 233160 & 225960 & 216060 & 200940 & 177600 & 137040 \\
\hline
\end{tabular}

Fonte: Authors (2018)

In where: $\mathrm{UL}$ = useful machine life; $\mathrm{DC}=$ depreciation coefficient; $\mathrm{RV}_{\mathrm{Ca}}=$ truck resale value obtained with the Caires method.

\section{RESULTS AND DISCUSSION}

The lowest monthly depreciation value was obtained by the Caires method ( $R \$ 1,630.25)$, followed by the Exponential, Linear and Cole methods ( $R \$ 2,276.64, R \$$ $2,400.96$ and $R \$ 2,422.40$, respectively) (Table 4). Depreciation was lower in situation G, corresponding to the longest truck's useful life (Figure 1).

Depreciation is one of the fixed costs that reduce the value and efficiency of machines in wood transport (ANDERSSON et al., 2015). Higher transport distances lead to more active transport and faster operational speed, reducing costs per ton of transported wood (GUIMARÃES et al., 2016).

The lower depreciation value estimated with the Caires method highlights its potential use in realistic conditions than the others methods, because it considers other factors besides the current age and the useful life of the machine and to adjust the model and the coefficients of use for specific situations. This represents more representative depreciation costs found in field situations, generating more real costs (BENVENHO; SABINO, 2013). Low depreciation values with the four methods were associated with the longest useful life of 8.33 years. Depreciation represents the truck's value over its useful life, and its value is lower when higher useful life rates are adopted (VIANA et al., 2013). 
Table 4 - Arbitrary depreciation value, depreciation by Linear, Exponential, Cole and Caires methods, in $\mathrm{R} \$ /$ month, and cost of transport by Linear, Exponential, Cole and Caires methods, in $\mathrm{R} \$ /$ ton, for each studied situation

\begin{tabular}{|c|c|c|c|c|c|c|c|c|c|}
\hline Sit. & ADV & $D_{L}$ & $D_{E}$ & $\mathbf{D}_{\mathrm{Co}}$ & $\mathbf{D}_{\mathrm{Ca}}$ & $\mathrm{CT}_{\mathrm{L}}$ & $\mathrm{CT}_{\mathrm{E}}$ & $\mathrm{CT}_{\mathrm{Co}}$ & $\mathbf{C T}_{\mathrm{Ca}}$ \\
\hline \multirow{2}{*}{ A } & $70 \%$ & 3605.77 & 10128.00 & 9680.35 & \multirow{2}{*}{2340.54} & 14.31 & 17.70 & 17.47 & \multirow{2}{*}{13.71} \\
\hline & $80 \%$ & 2403.85 & 10798.41 & 10459.98 & & 13.72 & 17.20 & 17.88 & \\
\hline \multirow{2}{*}{ B } & $60 \%$ & 4201.68 & 8475.91 & 8018.70 & \multirow{2}{*}{2340.34} & 14.99 & 17.20 & 16.96 & \multirow{2}{*}{14.03} \\
\hline & $70 \%$ & 3151.26 & 9042.83 & 8640.08 & & 14.45 & 17.49 & 17.28 & \\
\hline \multirow{2}{*}{ C } & $50 \%$ & 4496.40 & 7006.88 & 6612.36 & \multirow{2}{*}{2219.42} & 15.64 & 16.92 & 16.72 & \multirow{2}{*}{$14.4 \varepsilon$} \\
\hline & $60 \%$ & 3597.12 & 7482.21 & 7088.45 & & 15.19 & 17.16 & 16.96 & \\
\hline \multirow{2}{*}{ D } & $40 \%$ & 4504.50 & 5703.14 & 5428.51 & \multirow{2}{*}{2100.60} & 16.35 & 16.95 & 16.81 & \multirow{2}{*}{15.15} \\
\hline & $50 \%$ & 3753.75 & 6097.99 & 5775.01 & & 15.97 & 17.14 & 16.98 & \\
\hline \multirow{2}{*}{$E$} & $30 \%$ & 4196.64 & 4490.69 & 4370.70 & \multirow{2}{*}{1979.62} & 17.25 & 17.39 & 17.33 & \multirow{2}{*}{16.17} \\
\hline & $40 \%$ & 3597.12 & 4811.70 & 4602.77 & & 16.95 & 17.55 & 17.44 & \\
\hline \multirow{2}{*}{$\mathrm{F}$} & $20 \%$ & 3597.12 & 3365.51 & 3398.98 & \multirow{2}{*}{1834.53} & 18.72 & 18.62 & 18.63 & \multirow{2}{*}{17.91} \\
\hline & $30 \%$ & 3147.48 & 3620.32 & 3536.15 & & 18.52 & 18.73 & 18.69 & \\
\hline \multirow{2}{*}{ G } & $10 \%$ & 2701.08 & 2276.64 & 2422.40 & \multirow{2}{*}{1630.25} & 21.89 & 21.71 & 21.77 & \multirow{2}{*}{21.44} \\
\hline & $20 \%$ & 2400.96 & 2474.11 & 2486.71 & & 21.76 & 21.79 & 21.80 & \\
\hline
\end{tabular}

Source: Authors (2018)

In where: Sit. = situations studied; $A D V=$ arbitrary depreciation value; $D_{L}=$ depreciation by Linear method; $\mathrm{D}_{\mathrm{E}}=$ depreciation by Exponential method; $\mathrm{D}_{\mathrm{Co}_{\mathrm{o}}}=$ depreciation by Cole method; $\mathrm{D}_{\mathrm{Ca}}=$ depreciation by Caires method; $\mathrm{CT}_{\mathrm{L}}=$ cost of transport by Linear method; $\mathrm{CT}_{\mathrm{E}}=$ cost of transport by Exponential method; $\mathrm{CT}_{\mathrm{Co}_{\mathrm{o}}}=$ cost of transport by Cole method; $\mathrm{CT}_{\mathrm{Ca}}=$ cost of transport by Caires method.

The Exponential, Caires and Cole methods showed a marked decrease in depreciation in the initial years of the truck's useful life. The linear method presented a divergent behavior in relation to the other ones. The Exponential and Cole methods showed similar behavior of depreciation over the useful life (Figure 1A).

The Exponential, Caires and Cole methods are non-linear functions that normally generate sharp depreciation in the first years of the truck use (MORANDI; REIS, 2004). The o Linear method showed a divergent behavior from the other ones which was because this function implies a constant reduction in the useful life of the vehicle (JASPER; SILVA, 2013). The similar behavior between the Exponential and Cole methods evidenced the occurrence of sharp depreciation and consequent devaluation in the initial years of the vehicle life (FREITAS et al., 2007). 
The transport costs per wood ton was lower with the Caires method, $R \$ 13.71$, followed by the Linear, Cole and Exponential methods, $R \$ 13.72, R \$ 16.72$ and $R \$ 16.92$, respectively. The Caires method presents, in all situations, lower transport cost values in relation to the other methods (Figure 1B).

Figure1 - Depreciation ( $R \$ /$ month) $(A)$ and transport costs ( $\$ /$ ton) $(B)$ according to the useful life (years) for each studied methodology

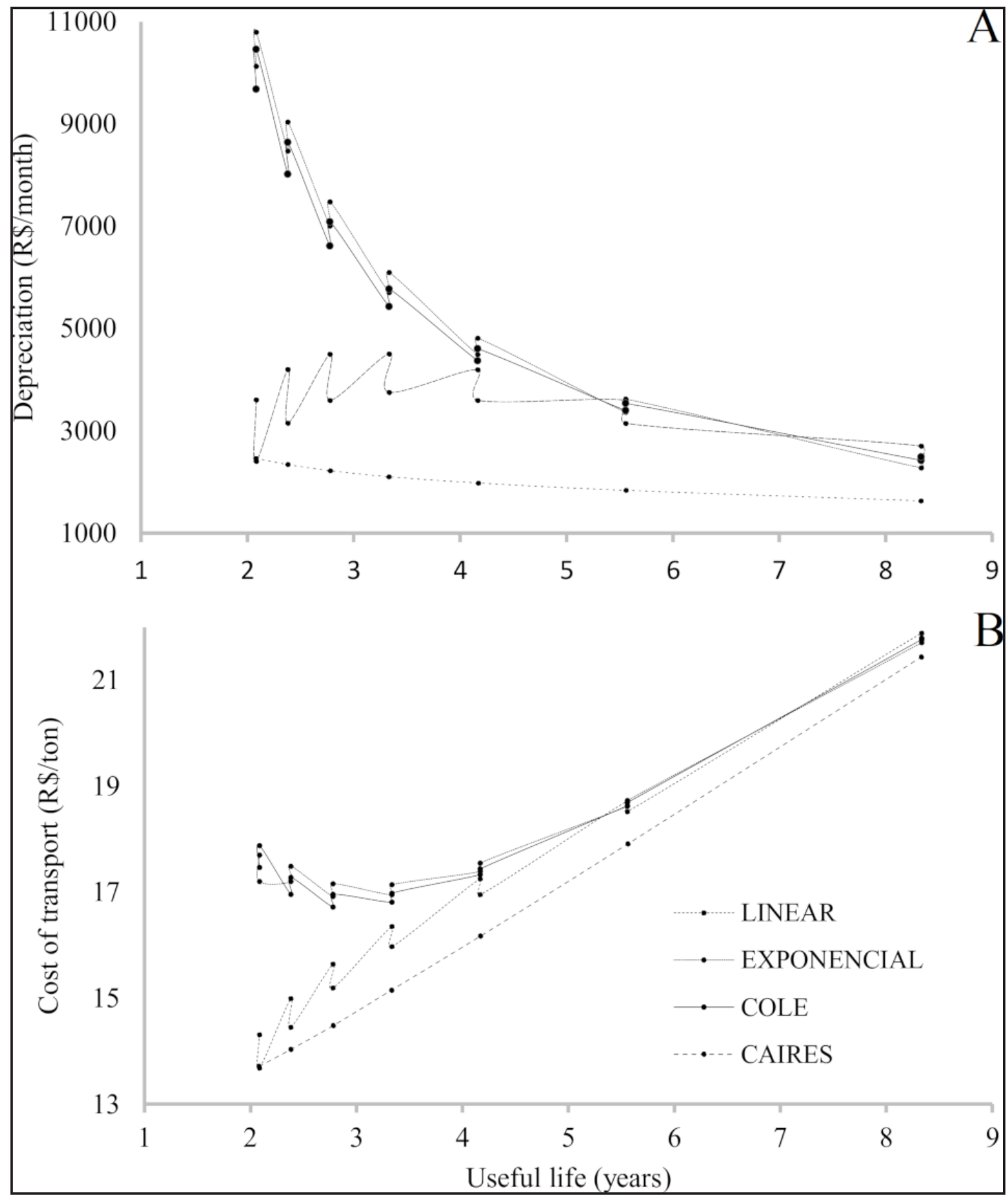

Source: Authors (2020) 
The lowest transport costs per wood ton, in all situations (Table 1), were obtained with the Caires method, because this method details the calculation of transport costs using maintenance and labor factors (SILVA et al, 2009). The difference of R $\$ 0.01$ per ton between the Caires and Linear methods, which is apparently small, represents annual savings of thousands of Reais, when we consider the large volumes of wood transported annually by pulp and paper companies.

Depreciation is directly related to the increase in opportunity costs for a company, since the capital allocated to this fixed cost is no longer used in other investments. (ZHANG et al., 2020).Thus, the savings generated by the appropriate choice of the best depreciation method indirectly represent the availability of financial resources for other areas of the companies. Studies developed by Kim et al. (2016) also showed that the use of the linear and series methods is only rational when the equipment has a short useful life, since these methods disregard, among other factors, the time value of the currency.

Transport costs per payload increased with the reduction of monthly mileage in the four methods studied. Transport costs decreased as the truck's monthly distance increased (Table 4).

The cost reduction per wood ton with the increase in the distance traveled demonstrates the dependence of the distance between the forest location and the consumption place and the performance of the transport trips (SILVA et al., 2016). Driving distance can significantly influence the composition of road transportation costs (GUIMARÃES et al., 2016). Lower monthly distances are related to lower production levels, generating little significant savings in cost composition (WANKE; FLEURY, 2006).

\section{CONCLUSION}

The depreciation and the wood transport costs were smaller by the Caires method in all the studied situations. The Linear method, commonly used by forest transport service providers, was inefficient in obtaining depreciation and transportation costs because it did not present the lowest values found. The Caires method, which details 
the calculation of transport costs using maintenance and labor factors, was the most suitable for the calculation of depreciation and generated more real transport costs, also representing a great saving of financial resources in the long term.

\section{ACKNOWLEDGEMENTS}

We thank Drs. Ricardo Alcántara-de la Cruz and Wellington Souto Ribeiro for their insightful comments, and the Conselho Nacional de Desenvolvimento Científico e Tecnológico (CNPq) for financial support.

\section{REFERENCES}

AGÊNCIA NACIONAL DE TRANSPORTES TERRESTRES (ANTT). Resolução no 4.810, de 19 de agosto de 2015. Estabelece metodologia e publica parâmetros de referência para cálculo dos custos de frete do serviço de transporte rodoviário remunerado de cargas por conta de terceiros. Brasília: Diário Oficial da União, 2015. Disponível em: https://www.in.gov.br/ materia/-/asset_publisher/Kujrw0TZC2Mb/content/id/32412351. Acesso em: 13 jun. 2020.

ALVES, R. T.; FIEDLER, N. C.; SILVA, E. N. et al. Análise técnica e de custos do transporte de madeira com diferentes composições veiculares. Árvore, Viçosa, v. 37, n. 5, p. 897-904, ago. 2013. Disponível em: https://www.scielo.br/pdf/rarv/v37n5/12.pdf. Acesso em: 22 mai. 2020.

ANDERSSON, M.; LUÍZ, N.; TAVARES MACHADO, A. L. et al. Índices de depreciação, ergonomia, segurança, nível de ruído e manutenção como parâmetros de avaliação em tratores agrícolas de quatro rodas. Rev. Fac. Agron. La Plata, v. 114, n. 1, p. 95-100, ago. 2015.

BAIO, F. H. R.; ANTUNIASSI, L. A.; BALASTREIRE, J. V. C. F. Modelo de programação linear para seleção de pulverizadores agrícolas de barras. Engenharia Agrícola, Jaboticabal, v. 24, n. 2, p. 355-363, mai./ago. 2004.

BENVENHO, A. C.; SABINO, A. G. Proposta de uso conjunto do método de Caires e RossHeidecke de modo a complementar e aprimorar a metodologia tradicional de avaliação de máquinas e equipamentos. In: CONGRESSO BRASILEIRO DE ENGENHARIA DE AVALIAÇÕES E PERÍCIAS (COBREAP), 17;. Florianópolis, 2013. Anais ... Florianópolis, 2013, p. 1-24. v. 1.

FREITAS, L. C.; SILVA, M. L.; MACHADO, C. C. Influência do cálculo de depreciação no imposto de renda e no fluxo de caixa de uma atividade de transporte florestal. Árvore, Viçosa, v. 31, n. 2, p. 257-264, jan. 2007.

GUIMARÃES, P. P.; ARCE, J. E.; LOPES, E. da S. et al. Modeling of fuel consumption for forest transportation. Rev. Caatinga, Mossoró, v. 92, n. 2, p. 496-506, dez. 2016.

INSTITUTO BRASILEIRO DE AVALIAÇÕES E PERÍCIAS DE ENGENHARIA (IBAPE). Engenharia de avaliações. São Paulo: PINI, 2007. 
JASPER, S. P.; SILVA, R. A. P. Estudo comparativo do custo operacional horário da mecanização agrícola utilizando duas metodologias para o estado de São Paulo. Nucleus, Ituverava, n. 10, v. 2, p. 119-126, out. 2013.

KIM, S.; KO, W.; YOUN, S. et al. Advanced depreciation cost analysis for a commercial pyroprocess facility in Korea. Nuclear Engineering and Technology, Daejeon, v. 48, n. 3, p. 733-743, Jan. 2016.

MORANDI, L.; REIS, E. J. Estoque de capital fixo no Brasil 1950-2001. In: SEMINÁRIO DE PESQUISA EPGE, 2005, João Pessoa. Anais... João Pessoa, 2004, p. 1-20. v. 1.

OLIVEIRA, A. M. Método comparativo - estatístico para avaliação de máquinas- e equipamentos. In: CONGRESSO BRASILEIRO DE ENGENHARIA DE AVALIAÇÕES E PERÍCIAS (COBREAP), 12, Belo Horizonte, 2003. Anais... Belo Horizonte, 2003, p. 119, v. 1.

OLIVEIRA, M. D. M.; MILAN, M. Ponto de renovação de tratores agrícolas de pneus: avaliação de uma frota. Rev. Econ. Agríc., São Paulo, v. 48, n. 1, p. 39-55, nov. 2001.

PIACENTINI, L. et al. Software para estimativa do custo operacional de máquinas agrícolas MAQCONTROL. Engenharia Agrícola, São Paulo, v. 32, n. 3, p. 609-623, mai./jun. 2012.

SILVA, E. N.; FIEDLER, N. C.; MCHADO, C. C. da et al. Avaliação de custos de dois modelos de harvester no corte de eucalipto. Ciência Florestal, Santa Maria, v. 24, n. 3, p. 741-748, jul. 2014.

SILVA, F.; MINETTE, L. J.; SOUZA, A. P. et al. Classification of forest roads and determination of route using Geographyc Information System. Árvore, Viçosa, v. 40, n. 2, p. 329-335, dez. 2016. Disponível em: https://www.scielo.br/scielo.php?pid=S0100-67622016000200329\&script=sci_ abstract. Acesso em: 08 fev. 2020.

SILVA, M. A.; MURAKAMI, R. A.; BENVENHO, A. C. et al. Novos conceitos de depreciações para máquinas e equipamentos. São Paulo: Instituto Brasileiro de Avaliações e Perícias de Engenharia (IBAPE), 2009.

VIANA, C. C.; SANTOS, C. M. V.; SOARES, L. A. C. F. et al. Implantação da depreciação no setor público e procedimentos contábeis: um estudo em uma instituição pública de ensino superior. Revista Contemporânea de Contabilidade, Florianópolis, v. 10, n. 20, p. 113-138, ago. 2013.

WANKE, P. F.; FLEURY, P. F. Transporte de cargas no Brasil: estudo exploratório das principais variáveis relacionadas aos diferentes modais e às suas estruturas de custos. Brasília: IPEA, set. 2006. p. 409-464.

ZHANG, Y.; XIAN, J.; HUANG, M. Online leasing strategy for depreciable equipment considering opportunity cost. Information Processing Letters, Guangzhou, jun. 2020. p. 105981. 


\section{Authorship Contribution}

\section{1 - Iara Silva Sampaio}

Forestry Engineer, MSc.

https://orcid.org/0000-0002-6286-095X•iarasampaioufv@gmail.com

Contribution: Conceptualization, Data curation, Formal Analysis, Investigation, Methodology, Project administration, Resources, Software, Supervision, Validation, Visualization, Writing - original draft, Writing - review \& editing

\section{2 - Carlos Cardoso Machado}

Forestry Engineer, Dr., Professor

https://orcid.org/0000-0002-2386-9791•machado@ufv.br

Contribution: Conceptualization, Investigation, Methodology, Resources, Software, Supervision, Validation, Visualization

\section{3 - Valéria de Fatima Silva}

Forestry Engineer, MSc.

https://orcid.org/0000-0001-9974-5683•enfvaleriasilva@gmail.com

Contribution: Supervision, Validation, Visualization, Writing - original draft

\section{4 - José Cola Zanuncio}

Forestry Engineer, Dr., Professor

https://orcid.org/0000-0003-2026-281X•zanuncio@ufv.br

Contribution: Supervision, Validation, Visualization, Writing - original draft

\section{How to quote this article}

Sampaio, I. S.; Machado, C. C.; Silva, V. F.; Zanuncio, J. C. Influence of the depreciation method on the wood transport cost. Ciência Florestal, Santa Maria, v. 31, n. 1, p. 145-156, 2021. DOI 10.5902/1980509832812. Available from: https://doi.org/10.5902/1980509832812. Accessed: xx abbreviated month 202x. 